\title{
PENGARUH PENERAPAN METODE PEMBELAJARAN RESITASI TERHADAP HASIL BELAJAR MATEMATIKA SISWA
}

\author{
Dedy Yusuf Aditya \\ Program Studi Teknik Informatika, Universitas Indraprasta PGRI \\ Email: Yusufadit42@yahoo.co.id,yusufadit42@gmail.com
}

\begin{abstract}
Abstrak
Penelitian ini bertujuan untuk mengetahui adanya pengaruh penerapan metode resitasi terhadap hasil belajar matematika siswa kelas VII SMP AT-TAQWA. Metode penelitian yang digunakan penulis adalah metode eksperimen. Populasi dalam penelitian ini adalah seluruh siswa SMP AT-TAQWA Jakarta Pusat tahun ajaran 2013-2014. Teknik sampling yang digunakan teknik simple random sampling, sebanyak 40 siswa. Data hasil penelitian diperoleh dari tes sumatif terhadap responden pada pokok bahasan garis dan sudut. Teknik pengujian hipotesis dengan menggunakan uji beda rata-rata (uji-t). Dari hasil pengujian hipotesis dapat disimpulkan ada pengaruh yang positif dari penerapan metode resitasi terhadap hasil belajar matematika.
\end{abstract}

Kata Kunci: Penerapan, Pembelajaran, Resitasi, Hasil Belajar.

\section{Pendahuluan}

Pendidikan memegang peranan yang sangat penting dalam menciptakan manusia-manusia yang berkualitas. Pendidikan juga dipandang sebagai sarana untuk melahirkan insan-insan yang cerdas, kreatif, terampil, bertanggung jawab, produktif dan berbudi pekerti luhur. Rendahnya kualitas pendidikan dapat diartikan sebagai kurang berhasilnya proses pembelajaran. Jika dianalisis secara makro penyebabnya bisa dari siswa, guru, sarana dan prasarana maupun model pembelajaran yang digunakan. Selain itu, minat dan motivasi siswa yang rendah, kinerja guru yang kurang baik serta sarana dan prasarana yang kurang memadai akan menyebabkan kurang berhasilnya instruksional.

Proses pembelajaran yang kurang berhasil dapat menyebabkan siswa kurang berminat untuk belajar. Minat siswa yang kurang ditunjukkan dari kurangnya aktivitas belajar, interaksi dalam proses pembelajaran dan persiapan siswa dalam mengikuti kegiatan belajar mengajar. Kenyataan ini tentu saja tidak terlalu mengejutkan karena hasil belajar anak-anak Indonesia juga tergolong relatif rendah terutama pada mata pelajaran eksakta seperti matematika.

Rendahnya nilai matematika tentu saja tidak lepas dari peran guru sebagai salah satu faktor yang menentukan keberhasilan dalam belajar. Sekolah sebagai wahana pendidikan formal mempunyai tujuan untuk mencerdaskan kehidupan bangsa. Oleh karena itu, mempersiapkan sekolah dengan segala sarana maupun prasarana pendidikan seperti perbaikan kurikulum, peningkatan kualitas guru dan peningkatan pelayanan sekolah pada masyarakat merupakan pekerjaan yang utama selain pekerjaan-pekerjaan yang lainnya. Kurikulum yang telah diperbaharui menyarankan agar kegiatan pengajaran tidak hanya satu arah dari guru saja, melainkan dua arah atau timbal balik antara guru dan murid. Dalam komunikasi dua arah guru harus aktif merencanakan, memilih, membimbing, dan menganalisa berbagai kegiatan yang dilakukan siswa, sebaliknya siswa diharapkan untuk aktif terlebih mental maupun emosional.

Proses belajar yang harus dilakukan siswa untuk mendapatkan keterampilan, menemukan, mengelola, menggunakan, dan mengkomunikasikan hal-hal yang telah ditemukan merupakan hasil belajar yang diharapkan. Guru sebagai pendidik harus menguasai bermacam-macam metode mengajar. Hal itu dimaksudkan agar para guru dapat melakukan pendekatan yang tepat untuk diterapkan pada tingkat perkembangan intelektual siswa. 
Menurut Novianti (2004), matematika berasal dari kata mathematics (Inggris), atau mathematica yang diambil dari kata mathematike (Yunani). Perkataan ini mempunyai akar kata mathema yang berarti ilmu pengetahuan atau ilmu. Mathematike berhubungan erat dengan kata lainnya yang serupa, yaitu mathenein, yang mengandung arti belajar (berpikir). Namun, arti matematika belum dijelaskan secara pasti. Menurut Kurniawati (dalam Russafendi, 1988), "matematika adalah ilmu tentang logika mengenai bentuk, susunan, besaran, dan konsep-konsep yang saling berhubungan satu sama lain yang terdiri dari tiga bagian; Aljabar, Analisis dan Geometri”. Matematika yang diajarkan di sekolah lazim dikenal dengan matematika sekolah. Peranan matematika sekolah adalah untuk mempersiapkan siswa agar sanggup menghadapi perubahan keadaan dalam kehidupannya melalui pola berpikir matematika.

Sementara di sisi lain, kita tahu bahwa matematika merupakan ilmu yang memiliki kecenderungan deduktif, aksiomatik, dan abstrak (fakta, konsep dan prinsip). Karakteristik matematika tersebut yang menyebabkan matematika menjadi suatu pelajaran yang sulit dan menjadi momok bagi siswa. Oleh sebab itu, pembelajaran matematika khususnya pada Sekolah Dasar membutuhkan perhatian yang sungguh-sungguh dari siswa, guru dan instansi pendidikan yang terkait. Dalam hal ini, perlu diciptakan suatu kondisi belajar yang menyenangkan sehingga proses pembelajaran matematika dapat menjadi kegiatan yang diminati siswa.

Matematika merupakan suatu pengetahuan dasar, karena matematika dianggap sebagai induk dari seluruh cabang ilmu pengetahuan. Sehingga matematika sangat penting dipelajari di setiap jenjang pendidikan. Dari pendidikan dasar (SD) sampai perguruan tinggi ilmu matematika masih dipelajari dan digunakan dalam memecahkan berbagai persoalan.

Dari hasil pengamatan yang telah dilakukan peneliti di SMP AT-TAQWA pada tanggal 04 Februari 2013, peneliti menemukan masalah dari cara belajar yang selama di jalani oleh siswa kelas VII SMP AT-TAQWA. Ternyata selama ini guru kelas yang mengajar kelas VII SMP AT-TAQWA terutama mata pelajaran matematika mengajar dengan cara klasik. Namun, menurut guru tersebut hanya metode tersebutlah yang cocok diterapkan terhadap siswa kelas VII SMP AT-TAQWA. Selain itu, juga didapati hasil belajar matematika siswa kelas VII SMP AT-TAQWA pada pokok bahasan sudut dan garis tergolong rendah dan dianggap belum berhasil.

Dari penjelasan di atas, peneliti mengambil masalah tentang bagaimana menemukan cara belajar yang cocok untuk mengajar matematika. Penulis mengambil suatu ide tentang metode belajar resitasi yaitu metode penugasan yang mungkin dapat diterapkan di kelas VII SMP AT-TAQWA. Hal ini dimaksudkan agar siswa lebih sering berlatih dan belajar secara mandiri dalam memecahkan permasalahan belajar matematika dan mengerjakan soal matematika.

Berdasarkan uraian di atas, peneliti tertarik untuk mengadakan penelitian yang berjudul "Pengaruh Metode Pembelajaran Resitasi terhadap Hasil Belajar Matematika Siswa Kelas VII SMP AT-TAQWA Jakarta Pusat pada Pokok Bahasan Garis dan Sudut pada Tahun Ajaran 2012-2013".

\section{Tinjauan Pustaka}

\section{Pengertian Metode Pembelajaran}

Metode adalah seperangkat langkah (apa yang harus dikerjakan) yang tersusun secara sistematis (urutannya logis). "Pembelajaran merupakan proses interaksi yang dilakukan oleh guru dan siswa, baik di dalam maupun di luar kelas dengan menggunakan berbagai sumber belajar sebagai bahan kajian". (Poedjiadi, 2005) 
Metode pembelajaran dapat diartikan sebagai cara yang digunakan untuk mengimplementasikan rencana yang sudah disusun dalam bentuk kegiatan nyata dan praktis untuk mencapai tujuan pembelajaran. Terdapat beberapa metode pembelajaran yang dapat digunakan untuk mengimplementasikan strategi pembelajaran, di antaranya: (1) ceramah; (2) demonstrasi; (3) diskusi; (4) simulasi; (5) laboratorium; (6) pengalaman lapangan; (7) brainstorming; (8) debat, (9) simposium, dan sebagainya.

Menurut Sudjana (2005), "metode pembelajaran ialah cara yang dipergunakan guru dalam mengadakan hubungan dengan siswa pada saat berlangsungnya pengajaran". Sedangkan Sutikno (2009) menyatakan "metode pembelajaran adalah cara-cara menyajikan materi pelajaran yang dilakukan oleh pendidik agar terjadi proses pembelajaran pada diri siswa dalam upaya untuk mencapai tujuan".

Metode pembelajaran dapat diartikan sebagai cara yang digunakan untuk mengimplementasikan rencana yang sudah disusun dalam bentuk kegiatan nyata dan praktis untuk mencapai tujuan pembelajaran. (Arif, 2011). Berdasarkan uraian di atas, dapat disimpulkan bahwa metode pembelajaran merupakan suatu cara yang dilakukan oleh seorang guru agar terjadi proses belajar pada diri siswa untuk mencapai tujuan.

Berdasarkan definisi/pengertian metode pembelajaran yang dikemukakan tersebut di atas, dapat disimpulkan bahwa metode pembelajaran merupakan suatu cara atau strategi yang dilakukan oleh seorang guru agar terjadi proses belajar pada diri siswa untuk mencapai tujuan. Benny A. Pribadi (2009) menyatakan, "tujuan proses pembelajaran adalah agar siswa dapat mencapai kompetensi seperti yang diharapkan. Untuk mencapai tujuan proses pembelajaran perlu dirancang secara sistematik dan sistemik". Banyak metode yang digunakan seorang guru dalam pembelajaran passing bawah bolavoli, antara lain dengan menggunakan metode pembelajaran inovatif dan konvensional.

\section{Metode Pembelajaran Resitasi Pengertian Metode Resitasi}

Salah satu metode yang digunakan dalam pengajaran PAI adalah metode resitasi. Metode resitasi adalah cara untuk mengajar yang dilakukan dengan jalan memberi tugas khusus kepada siswa untuk mengerjakan sesuatu di luar jam pelajaran. Pelaksanaannya bisa di rumah, di perpustakaan, dan lain-lain dan hasilnya dipertanggungjawabkan.

Sedangkan Slameto (2003) mengemukakan bahwa metode resitasi adalah cara penyampaian bahan pelajaran dengan memberikan tugas kepada siswa untuk dikerjakan di luar jadwal sekolah dalam rentangan waktu tertentu dan hasilnya harus dipertanggungjawabkan kepada guru. Metode resitasi adalah metode penyajian bahan dimana guru memberikan tugas tertentu agar siswa melakukan kegiatan belajar. Metode ini diberikan karena dirasakan bahan pelajaran terlalu banyak, sementara waktu sedikit.

Dari uraian di atas, dapat disimpulkan bahwa metode resitasi adalah pemberian tugas kepada siswa atau di luar jadwal pelajaran yang pada akhirnya dipertanggungjawabkan kepada guru yang bersangkutan. Metode resitasi merupakan salah satu pilihan metode mengajar seorang guru, dimana guru memberikan sejumlah item tes kepada siswanya untuk dikerjakan di luar jam pelajaran. Pemberian item tes ini biasanya dilakukan pada setiap kegiatan belajar mengajar di kelas, pada akhir setiap pertemuan atau akhir pertemuan di kelas.

Dalam pembelajaran agama islam, metode resitasi bisa digunakan untuk berbagai materi yang terkait erat dengan aspek knowledge, aspek afeksi dan psikomotor. Materi-materi yang 
bisa diajarkan dengan metode resitasi ini misalnya materi tentang sejarah islam, syarat dan rukun sholat.

\section{Pengajaran dengan Metode Resitasi}

Sebagaimana yang telah di jelaskan di atas, bahwa cara mengajar dengan resitasi adalah dengan pemberian tugas di luar jadwal pelajaran. Metode ini mengandung tiga unsur, antara lain: pemberian tugas, belajar, dan resitasi.

Tugas, merupakan suatu pekerjaan yang harus diselesaikan. Pemberian tugas sebagai suatu metode mengajar merupakan suatu pemberian pekerjaan oleh guru kepada siswa untuk mencapai tujuan pengajaran tertentu. Dengan pemberian tugas tersebut siswa belajar mengerjakan tugas. Dalam melaksanakan kegiatan belajar, siswa diharapkan memperoleh suatu hasil yaitu perubahan tingkah laku tertentu sesuai dengan tujuan yang telah ditetapkan.

Tahap terakhir dan pemberian tugas ini adalah resitasi yang berarti melaporkan atau menyajikan kembali tugas yang telah dikerjakan atau dipelajari. Jadi, metode pemberian tugas belajar dan resitasi atau biasanya disingkat metode resitasi merupakan suatu metode mengajar dimana guru membebankan suatu tugas, kemudian siswa harus mempertanggung jawabkan hasil tugas tersebut. Resitasi sering disamakan dengan "home work" (pekerjaan rumah), padahal sebenarnya berbeda. Pekerjaan rumah (PR) mempunyai pengertian yang lebih khusus, ialah tugas-tugas yang diberikan oleh guru, dikerjakan siswa di rumah.

Sedangkan resitasi, tugas yang diberikan oleh guru tidak sekedar dilaksanakan di rumah, melainkan dapat dikerjakan di perpustakaan, laboratorium, atau di tempat-tempat lain yang ada hubungannya dengan tugas/pelajaran yang diberikan.

Jadi, resitasi lebih luas daripada homework. Akan tetapi, keduanya mempunyai kesamaan, antara lain: mempunyai unsur tugas, dikerjakan oleh siswa dan dilaporkan hasilnya, serta mempunyai unsur didaktis pedagogis.

Tujuan pemberian tugas menurut pandangan tradisional, pemberian tugas dilakukan oleh guru karena pelajaran tidak sempat diberikan di kelas. Untuk menyelesaikan rencana pengajaran yang telah ditetapkan, maka siswa diberi tugas untuk mempelajari dengan diberi soal-soal yang harus dikerjakan di rumah. Kadang-kadang juga bermaksud agar anak-anak tidak banyak bermain. Sedangkan tugas diberikan dengan pandangan bahwa kurikulum itu merupakan segala aktivitas yang dilaksanakan oleh sekolah, baik kegiatan kurikuler, maupun ekstra kurikuler.

\section{Hasil Belajar Matematika \\ Belajar}

Belajar merupakan kegiatan bagi siswa dan merupakan proses dari perkembangan kehidupan manusia, melalui belajar manusia mengalami perubahan dalam kehidupannya. Perubahan tersebut tidak hanya terkait dengan permasalahan ilmu pengetahuan saja, tetapi juga kecakapan, ketrampilan, sikap, pengertian, harga diri, minat, watak, penyesuaian dan sebagainya.

Menurut Dimyanti dan Mudjiono (2006) bahwa:

"Belajar, perkembangan dan pendidikan merupakan hal yang menarik dipelajari. Ketiga hal tersebut berkaitan dengan pembelajaran. Perkembangan dialami dan dihayati pula oleh individu siswa. Sedangkan pendidikan merupakan kegiatan interaksi. Belajar merupakan tindakan dan perilaku siswa yang kompleks. Sebagai tindakan maka belajar hanya dialami oleh siswa sendiri. Siswa adalah pihak penentu terjadinya atau tidak terjadinya proses belajar. Proses belajar terjadi berkat siswa memperoleh sesuatu yang 
ada di lingkungan sekitar. Lingkungan yang dihadapi siswa berupa keadaan alam, bendabenda, hewan, tumbuh-tumbuhan, manusia, atau hal-hal yang dijadikan bahan belajar".

Menurut Skiner (dalam Dimyanti dan Mudjiono, 2006), belajar adalah suatu perilaku. Pada saat orang belajar maka responnya menjadi lebih baik. Sebaliknya, jika dia tidak belajar maka responnya menurun. Dalam belajar ditemukan tiga hal berikut: 1) kesempatan terjadinya peristiwa yang menimbulkan respon belajar, 2) respon si pembelajar, dan 3) konsekuensi yang bersifat menguatkan respon tersebut. Pemerkuat terjadi pada stimulus yang menguatkan konsekuensi tersebut. Sebagai ilustrasi, perilaku respon si pembelajar yang baik diberi hadiah, sebaliknya perilaku yang buruk diberi teguran atau hukuman.

Menurut Morgan (Purwanto, 2008), belajar adalah setiap perubahan yang relatif menetap dalam tingkah laku yang terjadi sebagai salah satu hasil dari latihan atau pengalaman. Masih dalam buku yang sama menurut Gagne (dalam Purwanto, 2008), belajar terjadi apabila suatu stimulus bersama dengan isi ingatan mempengaruhi siswa sedemikian sehingga perbuatannya (performance-nya) berubah dari waktu sebelum ia mengalami situasi itu kewaktu sesudah ia mengalami situasi tadi.

Menurut Witheringthon (dalam Munawaroh, 2010) bahwa "belajar adalah suatu perubahan dalam kepribadian yang menyatakan diri sebagai pola baru dari pada reaksi yang berupa kecakapan, sikap, kebiasaan, kepandaian, atau suatu pengertian”.

Dari beberapa teori yang telah dikemukakan di atas, maka dapat diambil sebuah kesimpulan bahwa belajar adalah suatu kegiatan dalam rangka menuju perkembangan yang bersifat relatif menetap dalam tingkah laku yang terjadi sebagai salah satu hasil dari latihan atau pengalaman.

\section{Hasil Belajar}

Masalah belajar adalah masalah yang selalu aktual dan dihadapi oleh setiap orang. Maka dari itu, banyak ahli-ahli membahas dan menghasilkan teori tentang belajar. Menurut Slameto (2003), belajar adalah suatu proses usaha yang dilakukan seseorang untuk memperoleh suatu perubahan tingkah laku yang baru secara keseluruhan sebagai hasil pengalamannya sendiri dalam interaksi dengan lingkungannya.

Menurut Sudjana (2005), hasil belajar adalah kemampuan yang dimiliki siswa setelah ia menerima pengalaman belajarnya. Secara singkat, hasil belajar adalah kemampuan yang dimiliki siswa setelah ia menerima pengalaman belajarnya. Dengan demikian, hasil belajar matematika adalah prestasi yang diperoleh dalam mempelajari konsep-konsep dan struktur yang terdapat di dalam matematika.

Hasil belajar tidak hanya dimaksudkan untuk menunjukkan kemampuan-kemampuan, tetapi juga memberikan umpan balik kepada siswa maupun guru. Bagi siswa, umpan balik ini akan memberikan informasi untuk mengetahui apakah dirinya telah berhasil ataupun gagal dalam mencapai tujuan pembelajaran yang diharapkan. Adapun bagi guru, hasil belajar diharapkan dapat memberikan informasi mengenai suksesnya metode pembelajaran yang telah disampaikan. Hal ini sebagai masukan bagi guru untuk mengetahui metode pembelajaran yang cocok untuk pembelajaran berikutnya.

Menurut Arikunto (1990), "hasil belajar adalah hasil akhir setelah mengalami proses belajar, perubahan itu tampak dalam perbuatan yang dapat diaamati, dan dapat diukur". Artinya, hasil belajar merupakan hasil terakhir atau juga disebut dengan hasil yang diterima oleh seorang siswa setelah dia melaksanakan proses belajar, hasil belajar ini dapat digunakan sebagai tolak ukur atau barometer tentang keberhasilan dari proses belajar. 
Menurut Nasution (1995) bahwa hasil adalah suatu perubahan pada diri individu. Perubahan yang dimaksud tidak halnya perubahan pengetahuan, tetapi juga meliputi perubahan kecakapan, sikap, pengrtian, dan penghargaan diri pada individu tersebut. Artinya, hasil belajar dapat dilihat pada diri seseorang dari perubahan yang ada pada individu yang telah melaksanakan proses belajar.

Belajar merupakan hasil belajar yang dicapai siswa melalui proses belajar mengajar yang optimal cenderung menunjukkan hasil yang berciri sebagai berikut:

1. Kepuasan dan kebanggaan yang dapat menumbuhkan motivasi pada diri siswa.

2. Menambah keyakinan akan kemampuan dirinya.

3. Hasil belajar yang dicapai bermakna bagi dirinya, seperti akan tahan lama diingatannya, membentuk perilakunya, bemanfaat untuk mempelajari aspek lain, dapat digunakan sebagai alat untuk memperoleh informasi dan pengetahuan yang lainnya.

4. Kemampuan siswa untuk mengontrol atau menilai dan mengendalikan dirinya terutama dalam menilai hasil yang dicapainya maupun menilai dan mengendalikan proses dan usaha belajarnya.

Hasil belajar adalah kemampuan-kemampuan yang dimiliki siswa setelah ia menerima pengalaman belajarnya. Individu yang belajar akan memperoleh hasil dari apa yang telah dipelajari selama proses belajar itu. Hasil belajar yaitu suatu perubahan yang terjadi pada individu yang belajar, bukan hanya perubahan mengenai pengetahuan, tetapi juga untuk membentuk kecakapan, kebiasaan, pengertian, penguasaan, dan penghargaan dalam diri seseorang yang belajar.

Menurut Purwanto (2008), evaluasi dalam pendidikan adalah penafsiran atau penilaian terhadap pertumbuhan dan perkembangan siswa menuju ke arah tujuan-tujuan dan nilai-nilai yang ditetapkan dalam kurikulum. Hasil penillaian ini pada dasarnya adalah hasil belajar yang diukur. Hasil penilaian dan evaluasi ini merupakan umpan balik untuk mengetahui sampai dimana proses belajar mengajar yang telah dilaksanakan.

Berdasarkan definisi-definisi di atas, dapat ditarik kesimpulan bahwa perubahan tingkah laku yang diperoleh sebagai hasil dari belajar adalah sebagai berikut:

1. Perubahan yang terjadi secara sadar.

2. Individu yang menyadari dan merasakan telah terjadi adanya perubahan yang terjadi pada dirinya.

3. Perubahan yang terjadi relatif lama. Perubahan yang terjadi akibat belajar atau hasil belajar yang bersifat menetap atau permanen.

4. Perubahan yang terjadi mencakup seluruh aspek tingkah laku.

5. Perubahan yang diperoleh individu dari hasil belajar adalah meliputi perubahan keseluruhan tingkah laku baik dalam sikap kebiasaan, keterampilan dan pengetahuan.

Dapat disimpulkan bahwa hasil belajar adalah kemampuan yang diperoleh siswa sebagai hasil dari apa yang dipelajarinya di sekolah, yang relatif menetap dalam potensi tingkah laku yang terjadi sebagai akibat dari latihan dengan pengetahuan.

\section{Matematika}

Berdasarkan etimologi perkataan matematika berarti ilmu pengetahuan yang diperoleh dengan bernalar. Di sisi lain, matematika dipandang sebagai ilmu tentang logika mengenai bentuk, susunan, besaran dan konsep-konsep yang berhubungan satu dengan lainnya dan terbagi dalam tiga bidang, yaitu aljabar, analisis dan geometri.

Menurut Novianti (2004), matematika berasal dari kata mathematics (Inggris), atau mathematica yang diambil dari kata mathematike (Yunani). Perkataan ini mempunyai akar 
kata mathema yang berarti ilmu pengetahuan atau ilmu. Mathematike berhubungan erat dengan kata lainya yang serupa, yaitu mathenein, yang mengandung arti belajar (berpikir). Namun arti matematika belum dijelaskan secara pasti.

Menurut Kurniawati (2005) bahwa matematika diartikan sebagai bahasa atau simbol matematika adalah bahasa yang dapat menghilangkan sifat kabur, majemuk, dan emosional. Matematika adalah metode berpikir logis, dan juga matematika adalah sarana berpikir. Yang dimaksudkan matematika adalah sarana berpikir di sini adalah bahwa matematika adalah wadah dimana seseorang dapat menyelesaikan suatu permasalahan dalam kehidupan seharihari melalu cara berpikir yang menggunakan logika dan dituangkan dalam bentuk matematis.

Matematika adalah sains mengenai kuantitas dan besaran, dapat diartikan sebagai bahwa matematika adalah kombinasi angka yang dapat digunakan untuk menentukan kuantitas dan besaran suatu dari hasil perhitungan matematis.

Menurut Setyadi (2009) bahwa matematika memiliki pengertian yang beragam, bergantung dari sisi mana orang memandang. Orang sering mengidentikkan matematika dengan aritmatika padahal makin banyak pengertian lain. Anggapan tentang matematika sebagai aritmatika terbukti dengan banyaknya orang yang memiliki pandangan bahwa matematika adalah ilmu yang berkenaan dengan angka atau bilangan dan kegiatan hitung menghitung seperti penjumlahan, pengurangan, perkalian dan pembagian.

Peneliti menyimpulkan dari pendapat beberapa para ahli, bahwa matematika adalah suatu ilmu yang penting dipelajari oleh setiap orang, terutama dipelajari di sekolah, karena matematika dapat digunakan untuk menyeleaikan permasalahan dalam kehidupan seharihari.

Matematika sekolah berfungsi mengembangkan kemampuan menghitung, mengukur, menurunkan dan menggunakan rumus matematika yang diperlukan dalam kehidupan seharihari di antaranya melalui materi pengukuran dan geometri, aljabar dan trigonometri. Matematika juga berfungsi mengembangkan kemampuan mengkomunikasi gagasan dengan bahasa melalui model matematika yang dapat berupa kalimat dan persamaan matematika, diagram, grafik atau tabel.

\section{Hasil dan Pembahasan}

\section{Data Hasil Belajar Matematika Kelas Eksperimen}

Dari hasil tes hasil belajar matematika siswa yang diajar dengan metode resitasi sebanyak 20 siswa yang dijadikan sampel penelitian diperoleh skor minimun 48 dan skor maksimum 88 , sehingga diperoleh rentang (jangkauan) 40. Berdasarkan analisis data diperoleh mean 68,65; median 68,875; modus 69,5; simpangan baku 10,26; dan variansi 113,19, mayoritas siswa (40\%) memiliki skor antara 65,5-74,5 dari skor maxsimum 100.

\section{Data Hasil Belajar Matematika Kelas kontrol}

Dari hasil tes hasil belajar matematika siswa yang diajar dengan metode klasikal sebanyak 20 siswa yang dijadikan sampel penelitian diperoleh skor minimun 32 dan skor maksimum 80, sehingga diperoleh rentang (jangkauan) 48. Berdasarkan analisis data diperoleh mean 59,5; median 59,8; modus 59; simpangan baku 12,61; dan variansi 158,95, mayoritas siswa (30\%) memiliki skor antara 51,5-61,5 dari skor maxsimum 100.

\section{Uji Persyaratan Analisis Data}

Data yang telah dikumpulkan selanjutnya diuji persyaratan analisis, yang meliputi uji normalitas setiap kelompok data dan uji homogenitas. Hasil pengujian homogenitas dari 
kedua kelompok data dengan menggunakan uji fisher menunjukan bahwa kedua kelompok data mempunyai varians yang sama atau homogen.

\section{Pengujian Hipotesis Penelitian}

Untuk mengetahui pengaruh dari penerapan metode resitasi terhadap hasil belajar matematika siswa, maka dilakukan perbandingan data antara hasil belajar matematika siswa yang diajar dengan metode resitasi dengan data hasil belajar matematika siswa yang diajar dengan klasikal, sehingga uji statistik yang digunakan adalah uji beda rata-rata (uji-t). Dari perhitungan diperoleh hasil uji-t sebesar 2,3192. Nilai $t$ tabel untuk dk 38 sebesar 2,0252. Karena 2,3192 > 2,0252 atau $t_{\text {hitung }}>t_{\text {tabel }}$, maka Ho ditolak yang artinya pada tingkat kepercayaan 95\% nilai hasil belajar matematika siswa yang diajar dengn metode resitasi lebih tinggi secara signifikan dibandingkan hasil belajar matematika siswa yang diajar dengan klasikal.

\section{Pembahasan Hasil Penelitian}

Berdasarkan hasil penelitian dan hasil pengujian hipotesis, maka terbukti bahwa penerapan metode pembelajaran resitasi berpengaruh terhadap hasil belajar matematika siswa. Hal ini menunjukan bahwa metode resitasi memberikan dampak yang positif terhadap hasil belajar matematika siswa dan metode resitasi sangat cocok diterapkan dalam pembelajaran matematika di sekolah.

Dari hasil penelitian ini, guru matematika harus dapat menerapkan dan mengembangkan metode pembelajaran resitasi dalam proses pembelajaran, agar metode resitasi dapat menjadi alternatif metode pembelajaran di kelas. Diharapkan dapat membantu mengatasi permasalahan rendahnya hasil belajar matematika siswa di sekolah.

Penerapan metode pembelajaran resitasi di kelas eksperimen menurut pengamatan mendapatkan hasil yang lebih maksimal dibandingkan dengan hasil yang diperoleh di kelas kontrol yang menggunakan metode klasikal. Secara umum, metode resitasi lebih dapat meningkatkan aktivitas belajar siswa di dalam kelas saat mengikuti pelajaran dan menghilangkan kejenuhan siswa saat mengikuti pelajaran. Hal tersebut sejalan dengan pernyataan yang dikemukakan oleh Sudjana (1992) yang menyatakan bahwa metode resitasi memiliki arti yang lebih luas dan membuat anak untuk aktif belajar baik secara individu maupun kelompok. Terjadinya peningkatan aktivitas siswa dikarenakan pada penerapan metode resitasi siswa dipaksa untuk memperbanyak waktu belajarnya di kelas dengan pemberian tugas-tugas setelah materi diberikan sehingga siswa terangsang untuk aktif mendengarkan dan mencatat penjelasan-penjelasan dari guru yang berguna untuk melaksanakan tugas setelah materi selesai diberikan. Selain itu, metode resitasi juga berdampak baik pada guru pengampu mata pelajaran yang menggunakan.

Guru dapat lebih aktif dan bervariasi dalam menyampaikan materi kepada siswa. Secara garis besar, penelitian yang dilakukan saat ini mendukung penelitian dan teori yang sudah ada sebelumnya, seperti contoh teori yang diberikan oleh Purwati (1997) yang mengatakan bahwa metode resitasi memberikan kesempatan lebih banyak kepada siswa sehingga mereka dapat lebih menghayati materi pelajaran yang telah diberikan.

Secara singkat apabila siswa semakin mendalami materi yang diajarkan maka siswa juga akan semakin baik dalam peningkatan prestasi belajar. Selama proses penerapan metode resitasi dari siklus satu sampai siklus dua memang masih mengalami hambatan dan masih terdapat kekurangan, namun dilihat dari hasil pengamatan pengaruh yang diberikan dengan penerapan metode resitasi cukup besar baik dari perilaku guru, perilaku siswa, maupun prestasi siswa. Kurangnya hasil yang didapatkan dengan penerapan metode resitasi pada penelitian yang telah dilakukan terlihat pada persentase skor perilaku siswa saat mengikuti 
proses belajar mengajar. Selain itu, tidak maksimalnya metode resitasi terlihat dari sedikitnya nilai post test siswa yang memenuhi KKM.

Walaupun ada kenaikan pada siklus kedua dibandingkan dengan siklus kesatu. Salah satu kurang maksimalnva hasil yang didapat dengan penerapan metode resitasi dikarenakan belum adanya disikusi yang baik antara guru dan siswa pada saat siswa mengeriakan tugas. Guru lebih banyak mengawasi saja dibandingkan memberi pancingan kepada siswa untuk berdiskusi tugas. Apabila diskusi antara guru dan siswa susah dapat berjalan dengan baik saat siswa mengerjakan tugas maka dapat dipastikan hasil yang didapat akan lebih optimal sesuai dengan pendapat yang dikemukakan oleh Moejiono (1993) (dalam Purwati, 1997) yang menyatakan bahwa penerapan metode pemberian tugas akan memberikan hasil optimal jika pemberian tugas diperhatikan berbagai syarat/prinsip pemberian tugas, salah satunya adalah diskusi tugas antara guru dan siswa. Ada beberapa fakta lain muncul dalam proses penelitian yang menyebabkan kurang maksimalnya hasil yang didapatkan, di antaranya tidak menerapkan metode resitasi.

\section{Simpulan dan Saran \\ Simpulan}

Berdasarkan hasil penelitian maka dapat disimpulkan bahwa hasil belajar matematika siswa kelas yang diajar dengan menggunakan metode pembelajaran resitasi lebih tinggi dari hasil belajar matematika siswa yang diajar dengan metode klasikal. Dengan kata lain, dapat disimpulkan terdapat pengaruh dari penerapan pembelajaran metode resitasi terhadap hasil belajar matematika siswa.

\section{Saran}

Berdasarkan hasil penelitian telah didapat, maka peneliti mengajukan beberapa saran bagi guru sebaiknya memilih metode atau pendekatan pembelajaran yang tepat dalam mengajar matematika. Dalam memilih metode pembelajaran agar mencapai tujuan yang diharapkan sebaiknya melihat latar belakang siswa yang akan diajar. Salah satu metode yang dapat digunakan dalam mengajar matematika adalah metode resitasi.

\section{Daftar Pustaka}

Arif, M. S. (2011). Pengertian Strategi, Metode, Taktik. [online]. http://blog.elearning.unesa.ac.id/m-saikhul-arif?p=3/. Diunduh 25 Juli 2016.

Arikunto, Suharsimi. (1990). Evaluasi Hasil Pembelajaran. Jakarta: Rineka Cipta.

Dimyanti dan Mudjiono. (2006). Belajar dan Pembelajaran. Jakarta: Rineka Cipta.

Kurniawati. (2005). Pengaruh Kecerdasan Emosional terhadap Prestasi Belajar Matematika. Jurnal Exacta, Vol. 12 No. 7 Tahun 2005.

Munawaroh. (2010). Pengaruh Metode Resitasi terhadap Prestasi Belajar Matematika. Jurnal Exacta, Vol 1 No. 17 Tahun 2010.

Nasution, Harun. (1995). Pendidikan Agama dalam Perspektif. Jakarta: Rineka Cipta.

Novianti. (2004). Pengaruh Pembelajaran CTL terhadap Hasil Belajar Matematika. Jurnal Exacta, Vol. 7 No. 28 Tahun 2004.

Poedjiadi, Anna. (2005). Sains dan Teknologi Masyarakat. Bandung: PT. Remaja Rosdakarya.

Pribadi, Benny. (2011). Metode Pembelajaran ASSURE. Jakarta: Dian Rakyat.

Purwanti. (1997). Keberhasilan Industri Kecil di Kabupaten Bantul. Skripsi. Yogyakarta: PKK IKIP. 
Purwanto. (2008). Administrasi \& suvervisi Pendidikan. Bandung: Remaja Rosdakarya.

Russefendi, E. T. (1988). Pengajaran Matematika Modern. Bandung: Tarsito.

Setyadi. (2013). Peranan Matematika dalam Pendidikan Sekolah Dasar. Jurnal Exacta, Vol. 18, No. 4 Tahun 2013.

Slameto. (2003). Belajar \& Faktor yang Mempengaruhinya. Jakarta: Rineka Cipta.

Sudjana, Nana. (2005). Penelitian Hasil Proses Belajar Mengajar. Bandung: PT. Remaja Rosdakarya.

Sutikno, M. S. (2009). Belajar dan Pembelajaran, Prospect. Bandung. 